Apidologie, 1980, 11 (4), 361-365.

\title{
RELATIONSHIPS BETWEEN CONSUMPTION OF A POLLEN SUPPLEMENT, HONEY PRODUCTION, AND BROODREARING IN COLONIES OF HONEYBEES APIS MELLIFERA L. I.
}

\author{
Keith M. DOULL'
}

\begin{abstract}
SUMMARY
Results of a year-long field test of a commercial pollen supplement have been analysed to examine the relationships between consumption of the supplement, honey production and broodrearing in the test colonies. The supplement had no significant effect on broodrearing and did not make any major contribution to the nutrition of the larvae. Nevertheless, colonies that received the supplement produced $38 \%$ more honey per colony and $28 \%$ more honey per bee than the colonies that did not receive any supplementary food. The failure of the supplement to influence broodrearing was due to the absence of specific phago-stimulants to elicit pollen feeding behaviour in nurse bees and to its high content of total sugars and low content of Crude Protein. It is suggested that the supplement was consumed in the main by bees that had completed the broodrearing phase of adult life and were responding to sugars in the food. In consuming the supplement the bees would have obtained additional protein and they would have had higher body protein at the onset of foraging. This in turn would have enhanced their longevity and productivity per bee and per colony.
\end{abstract}

\section{INTRODUCTION}

An analysis of relationships between pollen, broodrearing and the consumption of a commercial pollen supplement showed that there were positive correlations between the amount of pollen available and the rates of broodrearing and consumption of the supplement (DoulL, 1973).

1. Honorary Visiting Research Fellow, Department of Entomology, Waite Agricultural Research Institute, The. University of Adelaide, Glen Osmond, South Australia 5064. 
Productivity in the colonies that received the pollen supplement was substantially higher than productivity in the Control colonies (Doull and PURDIE, 1966). The results of the year-long experiment have now been analysed to examine the relationships between productivity, consumption of the pollen supplement and broodrearing in the test colonies.

\section{METHODS}

Five colonies received the pollen supplement continuously for one year, while five other colonies received no supplementary food, and served as Control colonies. Areas of sealed brood and stored pollen, together with weights of the hives and amounts of supplement consumed were recorded at 21 day intervals. Numbers of bees reared were calculated from areas of sealed brood on the basis of 420 cells $/ \mathrm{dcm}^{2}$ on each side of a brood comb. Amounts of honey produced were calculated from increases in hive weights over the year.

The hives were moved on three occasions to take advantage of changing floral conditions. Throughout the year, nectar and pollen available to the bees varied butween extreme scarcity and extreme abundance.

\section{RESULTS}

The results of the analysis are presented in Table 1 which shows means per hive for the various criteria in the five colonies in each group.

Although the Treatment colonies reared $11.95 \%$ more bees than the Control colonies this difference was not significant. But consumption of the supplement enhanced productivity, for honey production per colony increased by $38 \%$ while honey production per bee increased by $23 \%$ and these increases were significant.

Areas of stored pollen in the two groups did not differ significantly so that these increases in productivity must be ascribed to some effects of the pollen supplement on the productivity of individual bees.

TABL. 1. - Relationships between consumption of a commercial pollen supplement and honey production in honeybee colonies. Means per colony of five colonies in each group.

\begin{tabular}{l|c|c|c}
\hline \hline & $\begin{array}{c}\text { Treatment } \\
\text { Colonies }\end{array}$ & $\begin{array}{c}\text { Control } \\
\text { Colonies }\end{array}$ & $\begin{array}{c}\text { L.S.D. } \\
\boldsymbol{p}=0.05\end{array}$ \\
\hline No. of bees reared & 167,849 & 149,931 & N.S. \\
Honey/colony $(\mathrm{kg})$ & 344.586 & 249.7 & 83.625 \\
Honey/bee $(\mathrm{g})$ & 2.05 & 1.66 & .35 \\
Area of stored pollen $\left(\mathrm{dcm}^{2}\right)$ & 394.56 & 299.6 & N.S. \\
Supplement + consumed $(\mathrm{mg} /$ bee $)$ & 30.2 & - & \\
\hline \hline
\end{tabular}




\section{DISCUSSION}

Productivity in any colony of honeybees is influenced both by the population of adult bees and by productivity per bee and in general the productivity of individual bees increases as the population of the colony increases (MOELLER, 1961).

Throughout most of the experiment, the Treatment colonies contained noticeable numbers of shiny, almost hairless bees with frayed wings. HAYDAK (unpub.) identified these bees as active foragers that were older than the average foragers in Control colonies and concluded that consumption of the pollen supplement had enhanced the longevity of bees in the Treatment colonies.

This greater longevity would have meant that the populations of the Treatment colonies were higher than those in the Control colonies and so the potential productivity per colony and per bee was higher.

Foraging is the final activity of honeybees and any factor that enhances the vigour and lifespan of foraging bees must also enhance their productivity.

The lifespan of foraging bees depends upon their levels of body protein at the onset of foraging and on the rate of depletion of body protein. Thus for example KLEINSCHMIDT and Kondos (1976) found that while bees in colonies in which body protein exceeded $40 \%$ had an average lifespan of 56 days, bees whose body protein at the onset of foraging was low lived only 26 days.

Body protein is severely depleted in bees that have completed the broodrearing phase of adult life (MAURIzio, 1959) and is replenished by the pollen they consume in declining amounts until they are 17-18 days old (LINDAUER, 1953). But the bees' ability to respond to the feeding stimuli presented by pollen declines during this period while their ability to respond to stimuli presented by sugars increases (DoulL, 1980).

The pollen supplement contained $56 \%$ total sugars - on a Total Food basis and in consequence it is reasonable to assume that bees 12-18 days old would have fed on the supplement in response to this high content of sugars. In doing so they would obtain adventitious protein additional to that they obtained from feeding on pollen.

It may be assumed then that bees in the Treatment colonies had higher levels of body protein at the onset of foraging. Their vigour and longevity would thereby be enhanced and their honey production would have been higher than that of bees in the Control colonies that did not have access to this additional source of protein and so with lower body protein at the onset of foraging would have had shorter lifespans and so would have been less productive.

Productivity per colony and per bee varied throughout the year as bees were exposed to different floral conditions in a succession of honey-flows. A second paper will examine the relationships between consumption of a pollen supplement and honey 
production during a "pollen deficient honey flow " from Eucalyptus leucoxylon and will consider some possible new directions for research based on the results of these analyses.

Received for publication in July 1980.

\author{
RÉSUME \\ RELATIONS ENTRE LA CONSOMMATION D'UN COMPLÉMENT DE POLLEN, \\ LA PRODUCTION DE MIEL ET L'ÉLEVAGE DU COUVAIN CHEZ L'ABEILLE, APIS MELLIFERA L.
}

On a analysé les résultats d'un test portant sur un an d'un complément commercial de pollen pour chercher les relations entre la consommation du complément, la production de miel et l'élevage du couvain dans les colonies testées. Les analyses précédentes (Doull, 1973) avaient montré qu'il existait des corrélations positives entre l'élevage du couvain, la consommation du complément et la quantité de pollen disponible pour les abeilles.

L'analyse présentée dans cet article montre que le complément de pollen n'a pas eu d'effet significatif sur le taux d'élevage. La consommation du complément de pollen a pourtant conduit à une augmentation de $38 \%$ de la production de miel par colonie et de $28 \%$ de la production de miel par abeille comparée aux colonies témoins.

Le fait que le complément n'ait pas contribué à l'élevage a été attribué au fait que toutes les colonies étaient capables de conserver des réserves de pollen tout au long de l'année. En outre, le complément de pollen ne renfermait pas les phagostimulants qui déclenchent spécifiquement le comportement d'alimentation sur pollen chez les nourrices et contenait bien moins de protéines et plus de sucres totaux que le pollen stocké, qui est la nourriture protéinique naturelle de l'abeille.

Les résultats de l'expérience et des observations faites durant toute l'année suggèrent que le complément a été consommé principalement par les plus vieilles des abeilles occupées aux travaux intérieurs en réaction à la forte teneur en sucres. Ceci leur a fourni des protéines supplémentaires, ce qui leur a donné une plus forte teneur en protéines au début du butinage et de cette longévité accrue a découlé une productivité accrue par abeille.

\title{
ZUSAMMENFASSUNG
}

\section{BEZIEHUNGEN ZWISCHEN VERBRAUCH VON POLLENERSATZ, HONIGERTRAG} UND BRUTAUFZUCHT IN VOLLKERN DER HONIGBIENE, APIS MELLIFERA L., I.

Die Resultate eines Feldversuches mit einem kommerziellen Pollenersatzmittel über die Dauer eines Jahres wurden analysiert, um mögliche Zusammenhänge zwischen dem Verbrauch an Pollenersatzmittel, Honigproduktion und Brutaufzucht in den Versuchsvölkern zu ermitteln. Frühere Analysen (DouLL, 1973) hatten ergeben, dass positive Korrelationen zwischen der Brutaufzucht, dem Verbrauch des Ersatzmittels und der Menge des den Bienen zur Verfügung stehenden Pollens bestanden.

Die hier mitgeteilte Analyse zeigt, dass das Pollenersatzmittel keinen signifikanten Einfluss auf das Aussmass der Brutaufzucht hat. Aber der Verbrauch des Ersatzmittels führt zu einer Steigerung der Honigproduktion je Volk um $38 \%$ und eine Steigerung der Honigproduktion per Biene um $28 \%$, verglichen mit den Kontrollvölkern.

Die Tatsache, dass das Ersatzmittel die Brutaufzucht nicht beeinflusste, wird damit erklärt, dass alle Völker über den grössten Teil des Jahres Pollenreserven halten konnten. Ausserdem enthielt das Ersatzfutter nicht das Phagostimulans, das bei. den Pflegebienen das spezifische Pollenfressverhalten 
auslöst, und dass es weniger Protein und mehr Gesamtzucker enthält als gelagerter Pollen - die natürliche Eiweissnahrung der Honigbienen.

Die Ergebnisse des Versuchs und Beobachtungen über das ganze Jahr lassen vermuten, dass das Ersatzmittel infolge seines hohen Zuckergehaltes vornehmlich von alten Stockbienen aufgenommen wurde.

Das Ersatzfutter versorgte sie mit zusätzlichem Protein, so dass sie bei Beginn der Sammeltätigkeit mehr Körpereiweiss hatten, wodurch sowohl Langlebigkeit wie die Produktivität per Biene gesteigert wurde.

\section{REFERENCES}

DouLl K.M., 1973. - Relationships between pollen, broodrearing and consumption of pollen supplements by honeybees. Apidologie, $4: 285-293$.

Doull K.M., 1980. - The Nutrition of Honeybees. Waite Agricultural Research Institute Biennial Report 1978-1979 (in press).

Doutl K. M. and PURDie J. D., 1966. - Field tests with Krawaite pollen supplement. Australasian Beekeeper, 67 : 219-222.

KLenschmidT G. J. and Kondos A. C., 1976. - The effects of crude protein on colony performance. Australasian Beekeeper, 78 : 36-39.

LINDAUER M., 1953. - Division of labour in the honeybee colony. Bee World, 34 : 63-73, 85-90.

Maurizio A., 1959. - Factors affecting the lifespan of bees. Ciba Found. Symp. "The Lifespan of Animals *. 231-243.

Moeller F. E., 1961. - The relationship between colony populations and honey production. U.S.D.A. A.R.S. Prod. Res. Rept., 55. 